\title{
The Relationship of Giving Non Material Incentive by Principal and Work Commitment With Teacher Performance
}

\author{
Anisah", Yuskal Kusman', Tia Ayu Ningrum ${ }^{1}$ \\ ${ }^{1}$ Universitas Negeri Padang
}

\begin{tabular}{l} 
Article Info \\
\hline Article history: \\
Received Nov $12^{\text {th }}, 2018$ \\
Revised Nov $20^{\text {th }}, 2018$ \\
Accepted Dec $29^{\text {th }}, 2018$
\end{tabular}

\section{Keyword:}

Non Material Incentive Work Commitment Teacher Performance.

\begin{abstract}
The background of the research because there is poor performance of teachers. And the purpose of this research iss to see the relationship between non material incentive and work commitment with teacher performance. This research is a correlational quantitative research. The result of data analysis showes 1) The performance of teachers is in good category with achievement level $78,5 \%$; 2) Non material incentive is in good category with achievement level $75,6 \%, 3$ ) Commitment work is in good category with achievement level $72 \%, 4)$ There is significant relation between giving non material incentive and work commitment with teacher performance. Based on the calculation results of correlation test between non-material incentive variable with teacher performance is obtained $r_{\text {count }}$ equal to 0.248 while $r_{\text {table }}$ is 0,235 . Variable of non material incentive with work commitment variable is obtained $r_{\text {count }}$ equal to 0,426 while $r_{\text {table }}$ is 0,235 . Work commitment variable with teacher performance is obtained $r_{\text {count }}$ equal to 0,314 while $r_{\text {table }}$ is 0,235 . And the relation of giving non-material incentive and work commitment with teacher performance is obtained $r_{\text {count }} 0.338$ while $r_{\text {table }}$ is 0,235 . So that, there is relation between giving non material incentive and work commitment with teacher performance.
\end{abstract}

(C) 2018 The Authors. Published by Redwhitepress.

This is an open access article under the CC BY-NC-SA license

(https://creativecommons.org/licenses/by-nc-sa/4.0/

\section{Corresponding Author:}

Anisah

Universitas Negeri Padang

Email: anisahpisang78@gmail.com

\section{Introduction}

Teacher Performance is factor to product good quality in teaching and education that will implicate to ouput quality of education after pasiing at school(Karweti, 2010). Based on the observations at SMK Negeri Sawahlunto city obtained a picture that some teachers are less concerned about the implementation of learning.It is seen from the frequency of teachers using the same tools and learning media every semester and make the varians method but in reality in the process of teaching and learning the teacher just do the one method. That result can not stimulate students' interest in learning. This condition is influenced by giving the rewards by principals for outstanding teachers. The reward is influence to the performance of employees(Damayanti, 2013; Hidayat, 2016). Then, the compensation effect to performance(Dhermawan, 2012; Mustika, 2014; Posuma, 2013; Riyadi, 2011; Suwati, 2013). And (Murty, 2014; Prihantoro, 2012) said that affecting performance are commitment and compensation. So it can be seen that factors that affect teacher performance is compensation and work commitment. And in this study the researchers wanted to see the compensation of non-material incentives and work commitment to performance. 


\section{Method}

This research is a correlational research that is looking at the relationship between non material incentive and work commitment with teacher performance at SMK Negeri Kota Sawahlunto. The population in this study is all teachers of SMK Negeri Kota Sawahlunto which amounted to 131 people. The sample was taken based on the Slovin formula using proportional stratified random sampling technique and obtained a sample of 70 people. The research instrument used is a Likert scale questionnaire with five choices of answers that have been tested.Validity and reliability use the help of SPSS version 16.0.In this study to test the requirements analysis of the normality test and hypothesis testing.

\section{Results and Discussions}

\section{Description of Teacher Performance Data}

From the table, it is known that the quality indicators are in category good with the level of achievement of $78,5 \%$. The quantity indicators is in good categories with levels of achievement $78.4 \%$. And punctuality indicators is in good categories with levels of achievement $78 \%$.An indicator of the effectiveness is in good categories with the level of achievement of 78.6. So we can conclude $\mathrm{k}$ inerjaaverage overall teacher in the category $\mathrm{d}$ ith both achievement levels $785 \%$.

Table 1. AchievementIndicator Level ofTeacher Performance Variable

\begin{tabular}{|c|c|c|c|c|}
\hline No & Indicator & Average & $\begin{array}{ll}\text { Level of } \\
\text { Achievement }\end{array}$ & Category \\
\hline 1 & Quality & 3.94 & 78.8 & Good \\
\hline 2 & Quantity & 3.92 & 78.4 & Good \\
\hline 3 & Punctuality & 3.90 & 78 & Good \\
\hline 4 & Effectiveness & 3.93 & 78.6 & Good \\
\hline \multicolumn{2}{|c|}{ Average } & 3.92 & 78.5 & Good \\
\hline
\end{tabular}

But the percentage has not reached the category very well, which means the need for an increase in teacher performance in SMK Negeri Kota Sawahlunto. Teachersperformanceneeds to be improved through the quality of work, quantity, punctuality and effectiveness of use of resources better. From the research results obtained indicator of accuracy times has the lowest achievement level. Therefore, the indicators of timeliness need to be considered again with the expectation of teachers able to improve its performance through increased timeliness in carrying out the task.

Performance is important to help the achievement of planned goals, because performance is the result of work. (Wibowo, 2011) said that the performance is an implementation of the plan that has been prepared previously in the organization. Based on these opinions, it can be said that if there is not performance then all plan that has been prepared in organiasi will not be implemented, so that organizational goals will not be achieved.

Teacher performance is very important for school continuity. Thus the workings displayed by the teacher and the work of the teacher will support the success of the school and bring the school in achieving the goal. Teacher performance is low not only gives impact to the teacher's performance, but it also shows that the organization goals that have been set not achieved well. However the work program and teaching methods are well planned, the success of a school lies in the teacher performance. So what should be done to improve the performance of teachers is to improve the quality of work, timeliness, and effectiveness of resource use. Given the good performance of teachers, the school's goalswill be achieved optimally.

\section{Description of Non-Material Incentive Data}

From table, it can be seen that the award indicator is in good category with the achievement level 74 , $6 \%$, the indicator of praise is in good category with the achievement level of $76,6 \%$. So it can be concluded that the average non-material incentive overall is in good category with achievement level $75,6 \%$. However, the percentage has not reached the high category which means there is an need to increase the provision of non-material incentives by the principal at SMK Negeri Kota Sawahlunto. 
Table 2. Achievement Indicator Level of Non-Material Incentive Variable

\begin{tabular}{lllcl}
\hline No & Indicator & Average & $\begin{array}{c}\text { Level of } \\
\text { Achievement }\end{array}$ & Category \\
\hline $\mathbf{1}$ & appreciation & 3.73 & $74.6 \%$ & Good \\
\hline $\mathbf{2}$ & Praise & 3.83 & $76.6 \%$ & Good \\
\hline Average & 3.78 & $75.6 \%$ & Good \\
\hline
\end{tabular}

This suggests that the granting of non-material incentives by principals needs to be increased again through the provision of appropriate rewards and praise to achieve optimal results. Moreover, from the research results indicate that the award indicator got the lowest score. To that end, the principal needs to improve the provision of non-material incentives through giving appropriate rewards in order to improve teacher performance and work commitment.

According to (Sarwoto, 2010)non-material incentives are the power of peransang given to employees in the form of appreciation, inauguration based on his work performance. These non-material incentives may include, either oral or written praise, awarding of award certificates, formal titling. Non-material incentives can be provided in various forms. They are (1). Guaranteed good communication between superiors and subordinates, (2) Availability of entertainment, education and training, (3) The existence of awards in the form of recognition of work performance, (4) Giving praise both orally and in writing, (5) The existence of gratitude both formally and non formally.

Providing non-material incentives by school principals is essential to improve teacher performance and work commitment. With the existence of non-material incentives are adequate to make the teachers feel more appreciated his dedication as an educator, so it would be encouraging teachers to be more accountable to the task in hand. Thus the provision of non-material incentives through the provision of awards and praise sufficient to encourage performance improvement and work commitment of teachers.

\section{Description of Work Commitment Data}

From the table, it is known that the engagement indicators are in good category with the achievement level of $71.8 \%$. The loyalty indicator is in good category with the achievement level of $72 \%$ and the indicator of responsibility in the good category with the achievement level of $72 \%$. So it can be concluded that the overall work commitment overall is in good category with $72 \%$ achievement level.

Table 3. Achievement Indicator Level of Work Commitment

\begin{tabular}{|c|c|c|c|c|}
\hline No & Indicator & Average & $\begin{array}{l}\text { Level of } \\
\text { Achievement }\end{array}$ & Category \\
\hline 1 & Involvement & 3.59 & $71.8 \%$ & Good \\
\hline 2 & Loyalty & 3.6 & $72 \%$ & Good \\
\hline 3 & Responsible & 3.6 & $72 \%$ & Good \\
\hline \multicolumn{2}{|c|}{ Average } & 3.60 & $72 \%$ & Good \\
\hline
\end{tabular}

But the percentage has not reached the category very well, which means the need for an increase in teacher work commitments in SMKN Sawahlunto City. Teacher work commitment needs to be improved through better engagement, loyalty and responsibility. From the research result, the engagement indicator has the lowest achievement level. Therefore, the engagement indicator needs to be considered again with the expectation of teachers able to increase their work commitment through increased involvement in carrying out the task.

From the above description that needs to be done in increasing the work commitment is to increase the involvement in carrying out tasks, have loyalty to the task and organization. It have also a great responsibility on the implementation of the task. With a high work commitment, the achievement of school goals and national education objectives to be optimal. Organizational commitment is important to the organization because: (1) it is influential to turnover employees, (2) it is relates to performance that assumes that employees who are committed to the company tend to develop greater effort on the enterprise ((Morrison, 1997). And the steps that can be taken to increase commitment by (Armstrong, 2003), are as follows: (1) Involve employees in discussing the organization's goals and values, (2) talking to employees about what is happening and plan for the future that will affect them, (3) Involve the employee in establishing mutual expectations (both parties) so that they feel to own and implement those goals, (4) Take whatever steps to improve the quality of work, (5) Help the employee develops the skills and competencies to improve the ability to work both inside and outside the organization, (6) Do not give promises to give lifetime employment, 
simply say that the organization will try to provide job opportunities, (7) A finally, when delivering any message to employees, always remember that their frame of mind is not always the same.

\section{The Relationship Of Giving Non Material Incentive By Principal And Work Commitment With Teacher Performance}

Based on the results of the test persyar a tan analysis is the normality test, it is known that the values obtained by testing the normality greater than the significance level used $(\alpha=0.05)$. This indicates that allthree variables have normal distributed data. This shows that the provision in tif cent non-material by the principal and co mitmen work with the teacher's performance has thus distributed data normal.Dengan normality of the data requirements for each variable's data analysis has been fulfilled.

Based on the calculation of correlation test and correlation significance test, it can be concluded that there is a significant correlation between non material incentive and work commitment with teacher performance in Vocational High School of Negeri Sawahlunto at significance level 5\% or at $95 \%$ confidence

level. This is due to the acquisition of the correlation test, $r_{\text {count }}$ larger than $r_{\text {tables. }}$ It is $r_{\text {count }}=0,338>$ table $=$ 0,235 at significance level $5 \%$ or at $95 \%$ confidence level. So also with the acquisition of test results significance correlation, where $\mathrm{t}_{\text {count }}$ larger than $\mathrm{t}_{\text {tables. }}$. It is $\mathrm{t}_{\text {count }}=2,11>\mathrm{t}_{\text {table }}=2,000$ at significance level of $5 \%$ or at $95 \%$ confidence level.

From the results of these calculations, the hypothesis that there is a significant relationship between non-material incentives with teacher performance can be accepted. This shows that one of the factors that affect teacher performance is non material incentive. This reinforces one of the expert's opinions, (Moeheriono, 2012) said a well-designed incentive program will be very useful because it can improve employee performance. The high performance of a teacher will be greatly influenced by the nonmaterial incentives provided by the principal.(Damayanti, 2013; Hidayat, 2016) said that the award affects the performance of employees. Then Armstrong (2003: 37) also said that one way to gain work commitment is to reward, assure that employees are rewarded fairly according to their contribution, using both financial and non-financial rewards. So it can be seen that non-material incentives have a relationship with performance. Based on the description, non-material incentives given by the principal have a close relationship with teacher performance. If the non-material incentives provided by the principal are in good category then the teacher's performance will be high.

Aside from providing non-material incentives, commitment is also related to performance. This is known from the results of research and supported by previous research. (Dhermawan, 2012; Mustika, 2014; Posuma, 2013; Riyadi, 2011; Suwati, 2013) also states from the results of his research if the compensation effect on performance. And (Murty, 2014; Prihantoro, 2012) said that affecting performance among others is commitment and compensation .

Teacher who have a high working commitment will be seen from the involvement, loyalty and responsibility in carrying out the task. The high level of teacher's work commitment is strongly influenced by the non-material incentives provided by the principal through the provision of appropriate awards and praise. Based on the description, the provision of non-material incentives by the principal has a close relationship with teacher work commitments. If the non-material incentives provided by the principal are in the high category then the teacher's work commitment will be high.

\section{Conclusions}

From the results of the research can be concluded that the performance of teachers in vocational high school in Sawahlunto city is in good category. There is indicator that we must improve to get good category of The teacher performance. They are quality, quantity, punctuality and effectiveness. The non material incentive given by principle of the vocational high school in Sawahlunto city is in good category. There is indicator that we must improve to get good category of The non material incentive. They are appreciation and praise. The Job commitment of teachers in vocational high school in Sawahlunto city is in good category. There is indicator that we must improve to get good category of The Job commitment of teachers. Involvement, loyalty and responsible. There is a significant relationship between non-material incentives and work commitment with teacher performance in vocational high school in Sawahlunto city with $r_{\text {count }} 0.338$ at $95 \%$ confidence level. So that, to make teacher perfomance good that it must make the non material incentive and job commitment is good too. 


\section{References}

Armstrong, dan K. (2003). Dasar-dasar Pemasaran. Jakrta: Gramedia.

Damayanti. (2013). Pengaruh Kompensasi Dan Motivasi Kerja Terhadap Kinerja Karyawan Perusahaan Daerah Air Minum (PDAM). Jupe UNS, 2 (1).

Dhermawan, A. N. B. (2012). Pengaruh Motivasi Lingkungan Kerja, kompetensi dan Kompensasi Terhadap Kepuasaan Kerja dan Kinerja Pegawai Di Lingkungan Kantor Dinas Pekerjaan Umum Provinsi Bali., 6 (2), 173-184.

Hidayat, R. dan P. S. (2016). Analisis Pemberian Insentif dan Motivasi Terhadap Guru Pada MTS Nurul Huda Kalangayar Sedati. Jurnal Ekonomi Manajemen, 1 (1), 17-18.

Karweti, E. (2010). Pengaruh Kemampuan Manajerial Kepala Sekolah Dan Faktor Yang Mempengaruhi Motivasi Kerja Terhadap Kinerja Guru SLB Di Kabupaten Subang. Jurnal Penelitian Pendidikan, 11 No 2.

Moeheriono. (2012). Pengukuran Kinerja Berbasis Kompetensi. Jakarta: Rajawali pers.

Morrison. (1997). How Franchise Job Satisfaction And Personality Affect Performance, Organizational Commitment, Franchisor Relation and Intention to Remain. Journal Of Small Business Management.

Murty, W. A. dan G. H. (2014). Pengaruh kompensasi, motivasi dan komitmen Organisasional Terhadap Kinerja Karyawan Bagian Akuntasi. The Indonesian Accounting Rev, 2 (2).

Mustika, S. M. (2014). Pengaruh Insentif Finansial dan Insentif Non Finansial Terhadap Prestasi Kerja Karyawan. Universitas Diponogoro, Semarang.

Posuma, C. O. (2013). Kompetensi, Kompensasi dan Kepemimpinan, Pengaruhnya terhadap Kinerja Karyawan pada Rumah Sakit Ratumbuysang Manado. EMBA, 1 (4).

Prihantoro, A. (2012). Peningkatan Kinerja Sumber Daya Manusia Melalui Motivasi, Disiplin, Lingkungan Kerja. Jurnal Value Added, 8 (2).

Riyadi, S. (2011). Pengaruh Kompensasi Finansial, Gaya Kepemimpinan dan Motivasi Kerja Terhadap Kinerja Karyawan Pada Perusahaan Manufaktur di Jawa Timur. Jurnal Manajemen Dan Kewirausahaan, (13 (1)).

Sarwoto. (2010). Dasar-Dasar Organisasi dan Manajemen. Jakarta: Ghalia Indonesia.

Suwati, Y. (2013). Pengaruh Kompensasi dan Motivasi Kerja Terhadap Kinerja Karyawan pada PT Tunas Hijau Samarinda. E-Journal Ilmu Administrasi Bisnis, (1 (1)), 41-56.

Wibowo. (2011). Manajemen Kinerja. Jakarta: Rajawali pers. 